J. Dairy Sci. 101:9617-9617

https://doi.org/10.3168/jds.2018-101-10-9617

(c) American Dairy Science Association ${ }^{\circledR}, 2018$.

\title{
Corrigendum to "Short communication: Apparent efficiency of colostral immunoglobulin G absorption in Holstein heifers" (J. Dairy Sci. 100:3282-3286)
}

\author{
Jennifer Halleran, Hannah J. Sylvester, and Derek M. Foster
}

On page 3283, in the equation used to calculate apparent efficiency of absorption (AEA), estimated percent blood volume was multiplied by 0.7 to reflect the percent of BW that is plasma volume; it should have been multiplied by 0.07. All calculations and interpretations used the correct factor, and the corrected paragraph and equation are shown below.

Colostrum and serum IgG concentrations, calf weight, and the volume of colostrum fed were used to determine the AEA of each calf using the following equation:

$$
\begin{aligned}
& \mathrm{AEA}= \\
& \left\{\frac{\text { serum IgG concentration }(\mathrm{g} / \mathrm{L}) \times \mathrm{BW}(\mathrm{kg}) \times[0.07(\text { estimated } \% \text { blood volume })]}{\text { colostral } \operatorname{IgG} \text { concentration }(\mathrm{g} / \mathrm{L}) \times \text { volume colostrum administered }(\mathrm{L})}\right\} \times 100 .
\end{aligned}
$$

The authors regret the error.

\section{REFERENCES}

Halleran, J., H. J. Sylvester, and D. M. Foster. 2017. Short communication: Apparent efficiency of colostral immunoglobulin G absorption in Holstein heifers. J. Dairy Sci. 100(4):3282-3286. https://doi.org/10.3168/jds.2016-11904. 